\title{
Peptic ulcer at the end of the 20th century: biological and psychological risk factors
}

\author{
Susan Levenstein MD
}

S Levenstein. Peptic ulcer at the end of the 20th century: biological and psychological risk factors. Can J Gastroenterol 1999;13(9):753-759. The prevailing concept of peptic ulcer etiology has swung over entirely in just a few years from the psychological to the infectious, yet the rich literature documenting an association between psychosocial factors and ulcer is not invalidated by the discovery of Helicobacter pylori. Physical and psychological stressors interact to induce ulcers in animal models, concrete life difficulties and subjective distress predict the development of ulcers in prospective cohorts, shared catastrophes such as war and earthquakes lead to surges in hospitalizations for complicated ulcers, and stress or anxiety can worsen ulcer course. Many known ulcer risk factors, including smoking, nonsteroidal anti-inflammatory drug use, heavy drinking, loss of sleep and skipping breakfast, can increase under stress; the association of low socioeconomic status with ulcer is also accounted for in part by psychosocial factors. Among possible physiological mechanisms, stress may induce gastric hypersecretion, reduce acid buffering in the stomach and the duodenum, impair gastroduodenal blood flow, and affect healing or inflammation through psychoneuroimmunological mechanisms. Psychosocial factors seem to be particularly prominent among idiopathic or complicated ulcers, but they are probably operative in run of the mill $\mathrm{H}$ pylori disease as well, either through additive effects or by facilitating the spread of the organism across the pylorus, while gastrointestinal damage by nonsteroidal anti-inflammatory drugs can also be potentiated by stress. Although the clinical importance of peptic ulcer is fading along with the millenium, due to secular trends and new therapies, it remains worthy of study as a splendid example of the biopsychosocial model.

Key Words: Helicobacter pylori; Nonsteroidal antiinflammatory drugs; Peptic ulcer
L'ulcère gastroduodénal à la fin du $20^{\mathrm{e}}$ siècle : facteurs de risque biologiques et psychologiques

RÉSUMÉ : Le concept dominant de l'étiologie de l'ulcère gastroduodénal a viré complètement en quelques années du psychologique à l'infectieux, cependant, la riche littérature documentant une association entre les facteurs psychologiques et l'ulcère n'est pas invalidée par la découverte de Helicobacter pylori. Des facteurs psychologiques et physiques stressants interagissent pour induire des ulcères chez des modèles animaux ; les difficultés réelles de la vie ou un chagrin non fondé prédisent le développement d'ulcères dans des cohortes prospectives et des catastrophes partagées, comme la guerre ou les tremblements de terre, entraînent une poussée d'hospitalisations pour des complications dues aux ulcères. Le stress et l'anxiété peuvent aggraver l'ulcère. Ainsi, de nombreux facteurs de risque connus pour induire un ulcère, y compris le tabagisme, l'utilisation de médicaments anti-inflammatoires non stéroïdiens, l'alcoolisme, le manque de sommeil et le fait de sauter le petit déjeuner, peuvent augmenter sous l'effet du stress. De même, l'association entre un statut socioéconomique faible et l'ulcère s'explique en partie par des facteurs psychosociaux. Parmi les mécanismes physiologiques possibles, le stress peut induire une hypersécrétion gastrique, réduire le tamponnage de l'acide dans l'estomac et dans le duodénum, entraver le flux sanguin dans la région gastroduodénale, et nuire à la guérison ou maintenir l'inflammation par le biais de mécanismes psychoneuroimmunologiques. Les facteurs pyschosociaux semblent particulièrement dominants parmi les cas d'ulcères compliqués ou idiopathiques, mais ils contribuent probablement aussi à l'ulcère à $H$. pylori, soit par des effets additionnels ou en facilitant la dissémination bactérienne à travers le pylore. Le stress peut aussi aggraver les lésions gastrointestinales induites par les anti-inflammatoires. Bien que l'importance clinique de l'ulcère gastroduodénal s'estompe avec la fin du millénaire à cause des nouveaux traitements et des tendances séculaires, cette affection reste digne d'être étudiée comme un magnifique exemple du modèle biopsychosocial.

This mini-review was prepared from a presentation made at the World Congress of Gastroenterology, September 6 to 11, 1998, Vienna, Austria

Gastroenterology Division, San Camillo-Forlanini Hospital, Rome, Italy 
P eptic ulcer as we know it is a disease of the 20th century. After an early career as an occasional affliction of young Victorian women it swept to hyperendemicity among the generation of men born around 1900 (1), only to begin fading away as the century headed into its last stretch (2). Its final decline, following the discovery of Helicobacter pylori, promises to be nicely timed to coincide with the rollover from 1999 to 2000 . As the century ends, what will be the next phase in our concept of ulcer etiology? Can a synthesis be born out of the thesis of psychosomatics and the antithesis of infection? This review of the literature aims to contribute to that process by summarizing the current knowledge of the interactions between psychosocial and biological risk factors in peptic ulcer.

\section{THESIS: PSYCHOSOCIAL RISK FACTORS}

The advent of $H$ pylori has thrown doubt into many minds as to whether the older literature relating psychosocial factors to peptic ulcer may have been entirely fallacious - as fatally flawed as those unfortunate psychiatric tracts that, in the 1930s, attributed Down's syndrome to faulty parenting.

Researchers have been claiming to find psychological components in ulcer etiology for as long as the modern psychosomatic concept has existed (3). Careful examination of this literature using strict methodological criteria allows some of it to be discarded as anecdotal or irrelevant. The cross-sectional literature is particularly suspect because of the ever-present possibility that associations can be contaminated by recall bias and by the effects of disease. It should be said, though, that the best of the crosssectional studies are highly suggestive. One showed, for instance, that among recent-onset ulcer patients given the exhaustive and stringently scored Bedford College Life Events and Difficulties Scale (4), the rate of severe life difficulties during the six months preceding ulcer development was five times higher than that in controls carefully matched from the electoral rolls for age, sex and socioeconomic status (5). Similarly, though doubts remain as to the relevance of animal models to human peptic ulcer, the extensive animal literature $(6,7)$ shows unequivocally that not only physical stressors (8) but also purely psychological manipulations (6) can cause or facilitate erosion of the gastric and sometimes the duodenal mucosa in mammals ranging from rats to monkeys (9).

Several follow-up studies of defined cohorts have shown psychological distress $(10,11)$ and concrete life stressors such as unemployment (12) or being a prisoner of war (13-15) to increase the risk of incident peptic ulcer over the subsequent period. Other more subjective kinds of stress, including difficulties at work or with marriage or children have also proved to predict ulcer development in some prospective studies $(12,16,17)$.

A particularly convincing line of research has compared rates of ulcer in a defined geographical area before and after catastrophic events. The classic study by Spicer et al (18), published while World War II was still raging, showed a surge in the rate of perforated ulcers in a group of 16 London, United Kingdom hospitals during the months of intense German bombing. Uncomplicated gastric ulcers, and bleeding ulcers at both gastric and duodenal sites, similarly increased following the disastrous earthquake in Kobe, Japan (19). During a profound economic crisis in Bulgaria, upper gastrointestinal $x$-ray studies were more likely to reveal active ulcers than during the same period of the previous year (20). One clever study in Hong Kong engaged raters to estimate the degree of societal impact of current events on the population by examining newspaper headlines year by year between 1962 and 1985, and found an astonishing correlation of $r=0.57$ with the rate of hospitalization for perforated ulcers (21), with ulcer surgery rates peaking simultaneously with such events as sovereignty negotiations and a massive influx of refugees from Vietnam.

Although the old 'specificity hypothesis', which held that specific intrapsychic conflicts led to specific psychosomatic diseases (22), has fallen into disrepute as a general concept, there is some evidence that personality characteristics may be associated with peptic ulcer. Hostility and low ego strength have been found to be predictive of ulcer in cohort studies $(10,23)$. The many correlational studies with similar findings (24-27) are interesting but must be taken with a grain of salt, especially because chronic peptic ulcer can itself induce considerable distress, reflected in reversible changes in Minnesota Multiphasic Personality Inventory profiles (28).

Once an ulcer has developed, psychosocial factors can have a considerable effect on its course. Having a relatively high level of anxiety (29) or of self-reported stress $(30,31)$ at the time of diagnosis increases the nonhealing rate of duodenal ulcer. Depression and low socioeconomic status increase the frequency of symptoms after initial healing (32), while ongoing stress has been shown to increase the rate of documented relapse over several years (31).

One methodological shadow lies over even prospective reports of an association between stress and peptic ulcer: the possibility of confounding by nonpsychosocial risk factors such as smoking, socioeconomic status and use of nonsteroidal anti-inflammatory drugs (NSAIDs). Fortunately several studies have controlled for all three factors in multivariate analyses, and all found that associations with ulcer incidence $(10,11)$ and course (33) persist even after adjustment.

\section{ANTITHESIS: NONPSYCHOSOCIAL RISK FACTORS}

The two main causes of peptic ulceration are $H$ pylori and NSAIDs. Some writers have gone so far as to suggest that all ulcers are related to one or the other (34), but this seems not to be true, with $15 \%$ of ulcers or more falling into what may be termed an idiopathic category $(35-38)$.

The role of $H$ pylori has been amply reviewed $(36,39$. $42)$. Growth of this organism in the gastric mucosa sets up 
local inflammation that can develop into ulcer and can, especially under circumstances such as high duodenal acid load that induce gastric metaplasia in the duodenum and encourage the spread of $H$ pylori across the pylorus (36), lead to ulcer formation in the duodenum as well. NSAIDs are important causes of both hemorrhagic gastritis and peptic ulcer $(43,44)$.

Gastric hypersecretion is a classic and well-established risk factor for peptic ulcer development $(45,46)$. There is probably a hereditary component, reflected by levels of serum pepsinogen (47), though many environmental factors can also influence acid levels. The net effect of $\mathrm{H}$ pylori on acid secretion is still unclear $(45,48,49)$.

Other genetic influences are shown by the clustering of ulcer in families $(46,50)$ and by the special susceptibility to ulcers of individuals with type $\mathrm{O}$ blood (51).

Cigarette smoking is another important ulcer risk factor (52), whose destructive effect on mucosal defenses seems to be particularly active in the presence of $H$ pylori (34).

Irregular eating and especially skipping breakfast, which prolongs the nocturnal fast period, has recently emerged as a risk factor for ulcer development (10). Shift work (53), and more generally lack of sleep (10), also seem to promote ulcer formation, conceivably through effects on the hypothalamic-pituitary-adrenal axis (54).

Alcohol consumption has been found in some $(10,55)$ but not all studies $(56,57)$ to be a risk factor for peptic ulcer. The reason is probably related to a dose effect: alcohol in low to moderate amounts seems to toughen up the gastroduodenal mucosa, actually inducing a protective effect against ulceration (52) and facilitating healing (58). Only at high levels of alcohol consumption does a damaging effect become evident, whether based on stimulation of acid secretion, on a direct irritant effect on the mucosa or on replacement with calories from alcohol of calories from foods that would otherwise buffer gastric acid.

One ulcer risk factor sits on the fence between psychosocial and nonpsychosocial: low socioeconomic status. The association between low socioeconomic status and peptic ulcer (59) is due in large part to the strong inverse association of $\mathrm{H}$ pylori infection with socioeconomic status $(60,61)$, which reflects variations in hygienic conditions during childhood according to socioeconomic status $(62,63)$. Also contributing to the association is physical exertion on the job, which seems to be independently associated with ulcer $(43,64)$, perhaps because of stimulation of gastric acid secretion (65).

\section{PSYCHOSOCIAL FACTORS IN RELATION TO OTHER ULCER RISK FACTORS}

Interactions with health risk behaviours: A glance at the section entitled 'Antithesis: nonpsychosocial risk factors' reveals something interesting: most of the supposedly nonpsychosocial ulcer risk factors are actually behavioural characteristics that are likely to be adversely influenced by stress, including smoking, heavy drinking, poor sleep, skipping breakfast and even NSAID use $(10,66)$.

Anecdotal evidence has attributed the increased ulcer risk under stress to behavioural changes (20), and this kind of behavioural mediation can be confirmed by the observation that the stress-ulcer association is reduced by statistical adjustment for health risk behaviours. For example, the association of family problems and unemployment with subsequent ulcer development among women in the Alameda County Study was due in large part to behavioural factors such as smoking, alcohol excess, and irregular sleeping and eating habits (12), as was the association with psychological distress among the population as a whole (10). Lesser but measurable mediating effects of smoking and of acetylsalicylic acid (ASA) use have been shown in other prospective studies as well $(11,31,33)$.

Behavioural mediators, especially smoking $(31,33)$, may also be important in the influence of stress on ulcer course; recent increases in smoking accounted in one study for half of the effect of anxiety in impairing endoscopic healing (29).

Interactions with duodenal acid load - Gastric acid secretion: For many years it was assumed that the chief mechanism by which psychological factors promote peptic ulcer was through stimulation of gastric acid secretion $(55,67)$. There is some evidence that stress, distress or anxiety can elevate gastric acid secretion, from the classic studies of patients with gastric fistulas (68) through case studies of changes in secretion over time in relation to life stress (69) to studies of the acute effect of laboratory stressors (70. 74). Indirect evidence includes the association of psychosocial factors with serum pepsinogen $(55,67)$ and the prosecretory effect of physical effort (65). The literature is quite inconsistent, however, with some groups instead reporting stress to lower gastric secretion in nonhuman primates (75) and humans (76). The key to resolving this contradictory evidence may lie in a peculiarity of the physiological response to stress among individuals who are prone to duodenal ulcer, because this group seems particularly likely to respond to stress with hypersecretion $(69,77)$.

Motility: Above and beyond acid secretion, another reason for the increased duodenal acid load typical of duodenal ulcer is accelerated gastric emptying (78). While the usual effect of stress on gastric motility is in the direction of paralysis rather than stimulation $(79,80)$, some subgroups of dyspeptic patients have a paradoxical response to laboratory stressors $(81)$ that may be relevant to ulcer formation. Buffering: The third component of duodenal acid load is the degree to which acid is buffered in the stomach or the duodenum. Irregular eating habits during periods of life stress, especially skipping breakfast, is likely to reduce food buffering, while there is some evidence that stress may directly inhibit duodenal bicarbonate secretion (8), as does at least one stress-related behaviour, cigarette smoking (82).

Interactions with gastroduodenal blood flow: Circulatory 
changes are thought to be a major contributor to the type of gastric stress lesion that develops in the context of the intensive care unit, and some workers have found that gastroduodenal blood flow can be impaired by other kinds of stress (83). The relevance of these findings to clinical ulcer psychogenesis is unclear but may be substantial.

Interactions with socioeconomic status: As mentioned above, there are good reasons unrelated to psychology that may in part explain the increased risk of ulcer among individuals with low socioeconomic status (59). This suggests that much of the association between socioeconomic status and ulcer is due to confounding. But poverty is also a major source of stress, and multivariate analyses indicate that a large proportion of the association between socioeconomic status and ulcer is related to psychological distress and to differences in health risk behaviours between highand low-socioeconomic status individuals (84).

Interactions with NSAIDs: NSAID use is associated with psychological stress (10), for reasons that can be complex and circular.

Clinical experience shows that many individuals who feel stressed turn to ASA and other NSAIDs as tranquilizers or sleep aids, despite the lack of evidence for such effects in the medical literature. This means that use of NSAIDs joins other health risk behaviours as a potential mediator between stress and ulcer.

It is also true, however, that because of NSAID use, painful medical conditions can confound the association between stress and ulcer, artificially inflating it; the same chronic pain that leads to use of gastrolesive medications can also cause psychological stress. In this case the stress is not a cause of ulcer but an innocent bystander.

To complicate the issue further, psychosocial factors can, in turn, cause, or exacerbate, painful conditions. Such disorders as migraine, for instance, are notoriously influenced for the worse by psychological distress; in addition to direct psychophysiological pathways, symptoms can be worsened by stress-related alterations in patterns of sleep, eating, alcohol consumption and smoking. The phenomenon of somatization has other aspects as well, whereby depressed or anxious individuals are hyperaware of bodily sensations and particularly distressed by phenomena (intestinal contractions, muscle tension) that would normally be ignored (85).

Thus, psychological distress can lead to behavioural changes and other causes of pain, which can lead to the use of NSAIDs and also to further intensification of distress, which can lead to gastroduodenal lesions.

There is a limited amount of evidence that stress and NSAIDs may interact directly, or additively, as well. In one study of patients taking NSAIDs for inflammatory conditions (86), those who were characterized as being under stress were more likely to develop upper gastrointestinal bleeding.

In contrast, the interaction of NSAID lesions with $H$ pylori has paradoxical aspects. Though some workers have reported $\mathrm{H}$ pylori infection to increase the risk of ulcera- tion among NSAIDs-treated patients (87), others have reported that eradication of $H$ pylori does not improve and may even worsen the course of NSAID-related ulcers $(88,89)$, casting doubt on the clinical importance of any damaging interaction between these two prime ulcer risk factors.

Interactions with $H$ pylori: It is generally accepted that $\mathrm{H}$ pylori is the single most important risk factor for peptic ulcer (40). Only $20 \%$ of infected individuals ever develop an ulcer (37), however, so cofactors are clearly of vital importance. There is some clinical evidence that anxiety and other aspects of stress may contribute to the formation of ulcer in individuals with low intensity or absent $\mathrm{H}$ pylori infection (90). Stress may also have a potentiating effect, mediated by duodenal acid load, on the colonization of the duodenum by $H$ pylori because an acid environment decreases the protective effect of bile (91). There can also be stress-related decreases in mucosal defenses to $H$ pylori damage through behavioural mediators such as cigarette smoking (34).

Interactions with liver disease: Following a pattern that should by now be familiar, cirrhosis of the liver can be both a source and an effect of stress because it is a devastating disease, often caused by heavy alcohol consumption. Cirrhosis, which increases the risk of peptic ulcer through mechanisms largely related to changes in upper gastrointestinal blood flow and not to $H$ pylori (92), may, therefore, be a confounder or a mediator of stress in some cases, though it is too rare to have a substantial quantitative impact on the overall association between stress and ulcer. Interactions with immune and endocrine mediators: The rapidly expanding field of psychoneuroimmunology (93) holds some promise for elucidating the mechanisms that link psychosocial factors with peptic ulcer. It has been suggested, without any supportive evidence, that psychoneuroimmunological mechanisms might be active in $H$ pylori-related peptic ulcer (94), as they are in some other infections (95). In particular, it is possible that stress may affect the intensity of local inflammatory responses that help determine the onset and course of ulcer $(96,97)$ by influencing the production of cytokines that mediate the inflammation (98-100).

Stress can also stimulate thyrotropin-releasing hormone, which is a promoter of gastric ulceration (101). This interaction has not, however, been studied as yet in a clinical setting.

It is probably relevant to the impairment of ulcer healing by psychosocial factors that chronic or subacute real life stress has been shown to inhibit the healing of experimental lesions on the skin and in the oral cavity $(100,102,103)$. Corticosteroids, the classic stress hormones, seem to be responsible $(100,102)$.

Refractory and idiopathic ulcers: $\mathrm{H}$ pylori is turning out to be present in fewer ulcers than was first thought (35). Non-H pylori non-NSAID or idiopathic ulcers are particularly likely to be associated with hyperpepsinogenemia (104), which has been reported to be associated in turn 
with psychosocial factors $(55,67)$. In one provocative case study, duodenal ulcer persisted in the context of life stress even after $H$ pylori had been eradicated with the use of antibiotics (105). There is evidence that psychological vulnerability is more prominent among ulcer patients who have fewer biological risk factors (90), suggesting that psychosocial factors may be particularly active among the idiopathic subgroup, which is often refractory to therapy (106).

Complicated ulcers: Some workers have suggested that acute perforated duodenal ulcer is not associated with $H$ pylori infection (107), and others find an even lesser association with bleeding ulcer (108). While these findings have not been consistently replicated, they might contribute to explaining why population studies of complicated ulcer $(18,19,21)$ have shown a particularly marked influence of societal stressors on ulcer incidence.

\section{SYNTHESIS: THE LARGER PICTURE}

This review of the literature shows that there is excellent evidence for a role of psychosocial factors in the etiology of peptic ulcer, and suggests several plausible mechanisms. The key point is that, as with other risk factors (including $\mathrm{H}$ pylori), psychosocial ones are not active in all cases of ulcer. Peptic ulceration can result from a number of differ-

\section{REFERENCES}

1. Sonnenberg A, Sonnenberg GS. Epidemiology of ulcer disease. In: Domschke W, Konturek SJ, eds. The Stomach: Physiology, Pathophysiology and Treatment. Berlin: Springer-Verlag, 1993:215-27.

2. Sonnenberg A. Changes in physician visits for gastric and duodenal ulcer in the United States during 1958-1984 as shown by National Disease and Therapeutic Index (NDTI). Dig Dis Sci 1987;32:1-7.

3. Mittelmann B, Wolff HG. Emotions and gastroduodenal function: Experimental studies on patients with gastritis, duodenitis, and peptic ulcer. Psychosom Med 1942;4:5-61.

4. Brown GW, Harris TO. Social Origins of Depression: A Study of Psychiatric Disorder in Women. London: Tavistock Publications, 1978.

5. Gilligan I, Fung L, Piper DW, Tennant C. Life event stress and chronic difficulties in duodenal ulcer: A case control study. J Psychosom Res 1987;31:117-23.

6. Weiss JM. Effects of coping behavior with and without a feedback signal on stress pathology in rats. J Comp Physiol Psychol 1971;77:22-30.

7. Weiner H. From simplicity to complexity (1950-1990), the case of peptic ulceration - II; Animal Studies. Psychosom Med 1991;53:491-516.

8. Takeuchi K, Furukawa O, Okabe S. Induction of duodenal ulcers in rats under water-immersion stress conditions. Influence of stress on gastric acid and duodenal alkaline secretion. Gastroenterology 1986;91:554-63.

9. Natelson BJ, Dubois A, Sodetz FJ. Effect of multiple stress procedures on monkey gastroduodenal mucosa, serum gastrin and hydrogen ion kinetics. Am J Dig Dis 1977;22:888-97.

10. Levenstein S, Kaplan GA, Smith MW. Psychological predictors of peptic ulcer incidence in the Alameda County Study. J Clin Gastroenterol 1997;24:140-6.

11. Anda RF, Williamson DF, Escobedo LG, Remington PL, Mast EE, Madans JH. Self-perceived stress and the risk of peptic ulcer disease: A longitudinal study of US adults. Arch Intern Med 1992;152:829-33.

12. Levenstein S, Kaplan GA, Smith M. Sociodemographic characteristics, life stressors, and peptic ulcer: A prospective study. J Clin Gastroenterol 1995;21:185-92. ent etiological pathways $(47,104,109-113)$, some of which are likely to be more responsive to stress than others. We have suggested, for example, that complicated ulcers and those related to neither $\mathrm{H}$ pylori nor NSAIDs may be particularly susceptible to psychosocial influences.

The clinical importance of the role of psychosocial factors in the $\mathrm{H}$ pylori era is less clear because of the therapeutic revolution that has taken place. Although the old dictum, 'once an ulcer, always an ulcer', was never more than a half-truth, it has lost its residual validity now that antibiotic treatment for $\mathrm{H}$ pylori allows many patients the hope of an ulcer-free future unencumbered by medications, lifestyle limitations or the threat of surgery. With this therapeutic breakthrough, which followed close on the heels of the appearance of powerful antisecretory agents and is being abetted by a secular fall in ulcer incidence, peptic ulcer promises to become a disorder as insignificant in the new century as it was prominent in the old one. The practical importance of psychosocial factors will be overshadowed in most cases by powerful pharmacological tools. However, the theoretical importance of peptic ulcer as a splendid example of the biopsychosocial model (114-117) is not diminished by improvements in its therapy and should not be ignored by the research community as we move into the new millennium.

13. Goulston KJ, Dent OF, Chapuis PH. Gastrointestinal morbidity among World War II prisoners of war: 40 years on. Med J Aust 1995;143:6-10.

14. Gill G, Bell D. The health of former prisoners of war of the Japanese. Practitioner 1981;225:531-8.

15. Nice DS, Garland CF, Hilton SM, Baggett JC, Mitchell RE. Long-term health outcomes and medical effects of torture among US Navy prisoners of war in Vietnam. JAMA 1996;276:375-81.

16. Medalie JH, Stange KC, Zyzanski SJ, Goldbourt U. The importance of biopsychosocial factors in the development of duodenal ulcer in a cohort of middle-aged men. Am J Epidemiol 1992;136:1280-7.

17. Netterstrøm B, Kuel K. Peptic ulcer among urban bus drivers in Denmark. Scand J Soc Med 1990;18:97-102.

18. Spicer CC, Stewart DN, Winser DMR. Perforated peptic ulcer during the period of heavy air raids. Lancet 1944;i:14.

19. Aoyama N, Kinoshita Y, Fujimoto S, et al. Peptic ulcers after the Hanshin-Awaji earthquake: increased incidence of bleeding gastric ulcers. Am J Gastroenterol 1998;93:311-6.

20. Pomakov P, Gueorgieva S, Stantcheva J, Tenev T, Rizov A. Ulcères gastro-duodenaux pendant la periode d'une crise economique aigue.

J Radiol 1993;74:265-7.

21. Lam SK, Hui WM, Shiu LP, Ng MM. Society stress and peptic ulcer perforation. J Gastroenterol Hepatol 1995;10:570-6.

22. Alexander F, French TM. Studies in Psychosomatic Medicine. New York: The Ronald Press Company, 1948.

23. Mirsky A. Physiologic, psychologic, and social determinants in the etiology of duodenal ulcer. Am J Dig Dis 1958;3:285-313.

24. Feldman M, Walker P, Green JI, Weingarden K. Life events stress and psychosocial factors in men with peptic ulcer disease: $A$ multidimensional case-controlled study. Gastroenterology 1986;91:1370-9.

25. Christodoulou GN, Alevizos BH, Konstantakakis E. Peptic ulcer in adults: Psychopathological, environmental, characterological and hereditary factors. Psychother Psychosom 1983;39:55-62.

26. Alp MH, Court JH, Grant AK. Personality pattern and emotional stress in the genesis of gastric ulcer. Gut 1970;11:773-7.

27. McIntosh JH, Nasiry RW, Frydman M, Waller SL, Piper DW. 
The personality pattern of patients with chronic peptic ulcer: A case-control study. Scand J Gastroenterol 1983;18:945-50.

28. Jess $\mathrm{P}$, Eldrup J. The personality patterns in patients with duodenal ulcer and ulcer-like dyspepsia and their relationship to the course of the diseases. Hvidovre Ulcer Project Group. J Intern Med 1994;235:589-94.

29. Levenstein S, Prantera C, Scribano ML, Varvo V, Berto E, Spinella S. Psychologic predictors of duodenal ulcer healing. J Clin Gastroenterol 1996;22:84-9.

30. Whiten JT, Bright-Asare P. Stress may contribute to delayed duodenal ulcer (DU) healing by increased acid secretion. Gastroenterology 1984;86:1298.

31. Holtmann G, Armstrong D, Pöppel E, et al. Influence of stress on the healing and relapse of duodenal ulcers. Scand J Gastroenterol 1992;27:917-23.

32. Levenstein S, Prantera C, Varvo V, et al. Long-term symptom patterns in duodenal ulcer: psychosocial factors. J Psychosom Res 1996;41:465-72.

33. Armstrong D, Arnold R, Classen M, et al. RUDER - A prospective, two-year, multicenter study of risk factors for duodenal ulcer relapse during maintenance therapy with ranitidine. Dig Dis Sci 1994;39:1425-33.

34. Martin DF, Montgomery E, Dobek AD, Patrissi GA, Peura DA. Campylobacter pylori, NSAIDs, and smoking: Risk factors for peptic ulcer disease. Am J Gastroenterol 1989;84:1268-72.

35. Ciociola AA, McSorley DJ, Turner K, Sykes D, Palmer JBD. Helicobacter pylori infection rates in duodenal ulcer patients in the United States may be lower than previously estimated. Am J Gastroenterol 1999;94:1834-40.

36. Graham DY. Helicobacter pylori infection in the pathogenesis of duodenal ulcer and gastric cancer: a model. Gastroenterology 1997;113:1983-91.

37. Peek RM, Jr, Blaser MJ. Pathophysiology of Helicobacter pylori-induced gastritis and peptic ulcer disease. Am J Med 1997;102:200-7.

38. Peterson WL, Graham DY. Helicobacter pylori. In: Feldman M, Scharschmidt B, Sleisenger MH, eds. Gastrointestinal and Liver Disease. Pathophysiology, Diagnosis, Management, 6th edn. Philadelphia: WB Saunders, 1997:604-19.

39. Marshall BJ. Helicobacter pylori. Am J Gastroenterol 1994;89:S116-28.

40. NIH Consensus Development Panel on Helicobacter pylori in Peptic Ulcer Disease. Helicobacter pylori in peptic ulcer disease. JAMA 1994;272:65-9.

41. Peura DA. Ulcerogenesis: integrating the roles of Helicobacter pylori and acid secretion in duodenal ulcer. Am J Gastroenterol 1997;92(Suppl 4):8S-13S.

42. Soll AH, for the Practice Parameters Committee of the American College of Gastroenterology. Consensus statement: Medical treatment of peptic ulcer disease. JAMA 1996;275:622-9.

43. Sonnenberg A. Factors which influence the incidence and course of peptic ulcer. Scand J Gastroenterol 1988;(Suppl 155):119-40.

44. Levy M. Aspirin use in patients with major upper gastrointestinal bleeding and peptic ulcer disease. N Engl J Med 1974;290:1158-62.

45. Peterson WL, Barnett CC, Evans DJ Jr, et al. Acid secretion and serum gastrin in normal subjects and patients with duodenal ulcer: the role of Helicobacter pylori. Am J Gastroenterol 1993;88:2038-43.

46. Leoci C, Ierardi E, Chiloiro M, et al. Incidence and risk factors of duodenal ulcer. A retrospective cohort study. J Clin Gastroenterol 1995;20:104-9.

47. Chang FY, Lai KH, Wang TF, Lee SD, Tsai YT. Duodenal ulcer is a multifactorial disorder - the role of pepsinogen I. S Afr Med J 1993;83:254-66.

48. El-Omar E, Penman ID, Ardill JES, Chittajallu RS, Howie C, McColl KEL. Helicobacter pylori infection and abnormalities of acid secretion in patients with duodenal ulcer disease. Gastroenterology 1995;109:681-91.

49. Chandrakumaran K, Vaira D, Hobsley M. Duodenal ulcer, Helicobacter pylori, and gastric secretion. Gut 1994;35:1022-6.

50. Raiha I, Kemppainen H, Kaprio J, Koskenvuo M, Sourander L. Lifestyle, stress, and genes in peptic ulcer disease: a nationwide twin cohort study. Arch Intern Med 1998;158:698-704.

51. Hook-Nikanne J, Sistonen P, Kosunen TU. Effect of ABO blood group and secretor status on the frequency of Helicobacter pylori antibodies. Scand J Gastroenterol 1990;25:814-8.

52. Friedman GD, Siegelaub AB, Seltzer CS. Cigarettes, alcohol, coffee and peptic ulcer. N Engl J Med 1974;290:469-73.

53. Segawa K, Nakazawa S, Tsukamoto Y, et al. Peptic ulcer is prevalent among shift workers. Dig Dis Sci 1987;32:449-53.

54. Leproult R, Copinschi G, Buxton O, Cauter EV. Sleep loss results in an elevation of cortisol levels the next evening. Sleep 1997;20:865-70.

55. Walker P, Luther J, Samloff IM, Feldman M. Life events stress and psychosocial factors in men with peptic ulcer disease: II. Relationships with serum pepsinogen concentrations and behavioral risk factors. Gastroenterology 1988;94:323-30.

56. Gillies M, Skyring A. Gastric ulcer, duodenal ulcer and gastric carcinoma: A case-control study of certain social and environmental factors. Med J Aust 1968;9:1132-6.

57. Schubert TT, Bologna SD, Nensey Y, Schubert AB, Mascha EJ, Ma CK. Ulcer risk factors: Interactions between Helicobacter pylori infection, nonsteroidal use, and age. Am J Med 1993;94:413-8.

58. Sonnenberg A, Mûller-Lissner SA, Vogel E, et al. Predictors of duodenal ulcer healing and relapse. Gastroenterology $1981 ; 81: 1061-7$.

59. Current Estimates from the National Health Interview Survey: United States, 1983. DHHS Publication No (PHS) 86-1582. Washington: United States Department of Health and Human Services, June 1986.

60. Graham DY, Malaty HM, Evans DG, Evans DJ Jr, Klein PD, Adam E. Epidemiology of Helicobacter pylori in an asymptomatic population in the U.S.: Effect of age, race, and socioeconomic status. Gastroenterology 1991;100:1495-501.

61. Replogle ML, Glaser SL, Hiatt RA, Parsonnet J. Biologic sex as a risk factor for Helicobacter pylori infection in healthy young adults.

Am J Epidemiol 1995;142:856-63.

62. Malaty HM, Graham DY. Importance of childhood socioeconomic status on the current prevalence of Helicobacter pylori infection. Gut 1994;35:742-5.

63. Webb PM, T Knight, Greaves S, et al. Relation between infection with Helicobacter pylori and living conditions in childhood: evidence for person to person transmission in early life. Br Med J 1994;308:750-3.

64. Sonnenberg A, Sonnenberg GS. Occupational factors in disability pensions for gastric and duodenal ulcer. J Occup Med 1986;28:87-90.

65. Oektedalen O, Guldvog I, Opstad PK, Berstad A, Gedde-Dahl D, Jorde R. The effect of physical stress on gastric secretion and pancreatic polypeptide levels in man. Scand J Gastroenterol 1984;19:770-8.

66. Steptoe A, Wardle J, Pollard TM, Canaan L, Davies GJ. Stress, social support and health-related behavior: a study of smoking, alcohol consumption and physical exercise. J Psychosom Res 1996;41:171-80.

67. Weiner H, Thaler M, Reiser MF, Mirsky IA. Relation of specific psychological characteristics to rate of gastric secretion (serum pepsinogen). Psychosom Med 1957;19:1-10.

68. Wolf S. The psyche and the stomach: A historical vignette. Gastroenterology 1981;80:605-14.

69. Peters MN, Richardson CT. Stressful life events, acid hypersecretion, and ulcer disease. Gastroenterology 1983;84:114-9.

70. Magni G, Rizzardo R, Mario FD, Farini R, Aggio L, Naccarato R. Personality and psychological factors in chronic duodenal ulcer their interaction with biological parameters. Schweiz Arch Neurol Neurochir Psychiatr 1984;135:315-20.

71. Feldman M, Walker P, Goldschmiedt M, Cannon D. Role of affect and personality in gastric acid secretion and serum gastrin concentration: Comparative studies in normal men and in male duodenal ulcer patients. Gastroenterology 1992;102:175-80.

72. Gundry RK, Donaldson RM, Pinderhughes CA, Barrabee E. Patterns of gastric acid secretion in patients with duodenal ulcer: Correlations with clinical and personality features. Gastroenterology 1967;52:176-84.

73. Holtmann G, Kriebel R, Singer MV. Mental stress and gastric acid secretion: Do personality traits influence the response? Dig Dis Sci 1990;35:998-1007.

74. Jess P. Gastric acid secretion in relation to personality, affect and 
coping ability in duodenal ulcer patients. A multivariate analysis. Hvidovre Ulcer Project Group. Dan Med Bull 1994;41:100-3.

75. Dubois A, Natelson BJ. Habituation of gastric function suppression after repeated free operant responses. Physiol Psychol 1978;6:524-8.

76. Hojgaard L, Bendtsen F. Gastric potential difference and $\mathrm{pH}$ in ulcer patients and normal volunteers during Stroop's colour word conflict test. Gut 1989;30:782-5.

77. Bresnick WH, Rask-Madsen C, Hogan DL, Koss MA, Isenberg JI. The effect of acute emotional stress on gastric acid secretion in normal subjects and duodenal ulcer patients. J Clin Gastroenterol 1993;17:117-22.

78. Fordtran JS, Walsh JH. Gastric acid secretion rate and buffer content of the stomach after eating: Results in normal subjects and in patients with duodenal ulcer. J Clin Invest 1973;52:645-57.

79. Holtmann G, Singer MV, Kriebel R, Stacker KH, Goebell H. Differential effects of acute mental stress on interdigestive secretion of gastric acid, pancreatic enzymes, and gastroduodenal motility. Dig Dis Sci 1989;34:1701-7.

80. Kellow JE, Langeluddecke PM, Ickersley GM, Jones MP, Tennant CC. Effects of acute psychologic stress on small-intestinal motility in health and the irritable bowel syndrome. Scand J Gastroenterol $1992 ; 27: 53-8$.

81. Hausken T, Svebak S, Wilhelmsen I, et al. Low vagal tone and antral dysmotility in patients with functional dyspepsia. Psychosom Med 1993;55:12-22.

82. Ainsworth MA, Hogan DL, Koss MA, Isenberg JI. Cigarette smoking inhibits acid-stimulated duodenal mucosal bicarbonate secretion. Ann Intern Med 1993;119:882-6.

83. Kauffman GL. Stress, the brain, and the gastric mucosa. Am J Surg 1997;174:271-5.

84. Levenstein S, Kaplan GA. Socioeconomic status and ulcer: A prospective study of contributory risk factors. J Clin Gastroenterol $1998 ; 26: 14-7$.

85. Lipowski ZJ. Somatization: the concept and its clinical application. Am J Psychiatry 1988;145:1358-68.

86. Hochain P, Berkelmans I, Czernichow P, et al. Which patients taking non-aspirin non-steroidal anti-inflammatory drugs bleed? A case-control study. Eur J Gastroenterol Hepatol $1995 ; 7: 419-26$.

87. Heresbach D, Raoul JL, Bretagne JF, et al. Helicobacter pylori: a risk and severity factor of non-steroidal anti- inflammatory drug induced gastropathy. Gut 1992;33:1608-11.

88. Chan FK, Sung JJ, Suen R, et al. Does eradication of Helicobacter pylori impair healing of nonsteroidal anti-inflammatory drug associated bleeding peptic ulcers? A prospective randomized study. Aliment Pharmacol Ther 1998;12:1201-5.

89. Hawkey CJ, Tulassay Z, Szczepanski L, et al. Randomised controlled trial of Helicobacter pylori eradication in patients on non-steroidal anti-inflammatory drugs: HELP NSAIDs study. Helicobacter Eradication for Lesion Prevention. Lancet 1998;352:1016-21.

90. Levenstein S, Prantera C, Varvo V, et al. Patterns of biologic and psychologic risk factors for duodenal ulcer. J Clin Gastroenterol 1995;21:110-7.

91. Han SW, Evans DG, el-Zaatari FA, Go MF, Graham DY. The interaction of $\mathrm{pH}$, bile, and Helicobacter pylori may explain duodenal ulcer. Am J Gastroenterol 1996;91:1135-7.
92. Tsai CJ. Helicobacter pylori infection and peptic ulcer disease in cirrhosis. Dig Dis Sci 1998;43:1219-25.

93. Ader R, Felten DL, Cohen N. Psychoneuroimmunology, 2nd edn. San Diego: Academic Press Inc, 1991.

94. Dotevall G. Peptic ulcer, noxious stress, and Campylobacter pylori. Gastroenterology 1990;98:252-3.

95. Kiecolt-Glaser JK, Glaser R, Gravenstein S, Malarkey WB, Sheridan J. Chronic stress alters the immune response to influenza virus vaccine in older adults. Proc Natl Acad Sci USA 1996;93:3043-7.

96. Uemura N, Oomoto Y, Mukai T, et al. Gastric corpus IL-8 concentration and neutrophil infiltration in duodenal ulcer patients. Aliment Pharmacol Ther 1997;11:793-800.

97. Arakawa T, Watanabe T, Fukuda T, et al. Ulcer recurrence: cytokines and inflammatory response-dependent process. Dig Dis Sci 1998;43(Suppl 9):61S-6S.

98. Persoons JH, Moes NM, Broug-Holub E, Schornagel K, Tilders FJ, Kraal G. Acute and long-term effects of stressors on pulmonary immune functions. Am J Respir Cell Mol Biol 1997;17:203-8.

99. McCarthy DO, Ouimet ME, Daun JM. The effects of noise stress on leukocyte function in rats. Res Nurs Health 1992;15:131-7.

100. Marucha PT, Kiecolt-Glaser JK, Favagehi M. Mucosal wound healing is impaired by examination stress. Psychosom Med 1998;60:362-5.

101. Hernandez DE. Neurobiology of brain-gut interactions: Implications for ulcer disease. Dig Dis Sci 1989;34:1809-16.

102. Kiecolt-Glaser JK, Marucha PT, Malarkey WB, Mercado AM, Glaser R. Slowing of wound healing by psychological stress. Lancet 1995;346:1194-6

103. Padgett DA, Marucha PT, Sheridan JF. Restraint stress slows cutaneous wound healing in mice. Brain, Behavior, and Immunity 1998;12:64-73.

104. McColl KEL, El-Nujumi AM, Chittajallu RS, et al. A study of the pathogenesis of Helicobacter pylori negative chronic duodenal ulceration. Gut 1993;34:762-8.

105. Miwa H, Matsushima H, Terai T, et al. Relapsed duodenal ulcer after cure of Helicobacter pylori infection. J Gastroenterol 1998;33:556-61.

106. Lanas AI, Remacha B, Esteva F, Sainz R. Risk factors associated with refractory peptic ulcers. Gastroenterology 1995;109:1124-33.

107. Reinbach DH, Cruickshank G, McColl KE. Acute perforated duodenal ulcer is not associated with Helicobacter pylori infection.

Gut 1993;34:1344-7.

108. Tokunaga Y, Hata K, Ryo J, Kitaoka A, Tokuka A, Ohsumi K. Density of Helicobacter pylori infection in patients with peptic ulcer perforation. J Am Coll Surg 1998;186:659-63.

109. Lam SK, Sircus W. Studies on duodenal ulcer, I. The clinical evidence for the existence of two populations. Q J Med 1975;44:369-87.

110. Spiro HM. Peptic ulcer is not a disease - only a sign. J Clin Gastroenterol 1987;9:623-4.

111. Rotter JI, Rimoin DL. Peptic ulcer disease - A heterogeneous group of disorders? Gastroenterology 1977;73:604-7.

112. Lam SK. Aetiological factors of peptic ulcer: perspectives of epidemiological observations this century. J Gastroenterol Hepatol 1994;9(Suppl 1):S93-8.

113. Spiro HM. Peptic ulcer: Moynihan's or Marshall's disease? Lancet $1998 ; 352: 645-6$

114. Weiner H. [Reductionism once again. The example of Helicobacter pylori]. Psychother Psychosom Med Psychol 1998;8:425-9.

115. Levenstein S. Stress and peptic ulcer: Life beyond Helicobacter. Br Med J 1998;316:538-41.

116. Levenstein S, Ackerman S, Kiecolt-Glaser JK, Dubois A. Stress and peptic ulcer disease. JAMA 1999;281:10-1.

117. Drossman DA. Gastrointestinal illness and the biopsychosocial model. J Clin Gastroenterol 1996;22:252-4. 


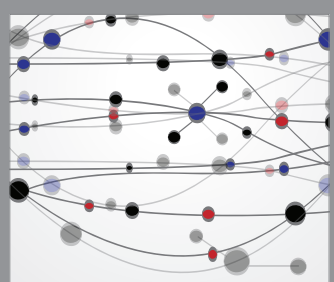

The Scientific World Journal
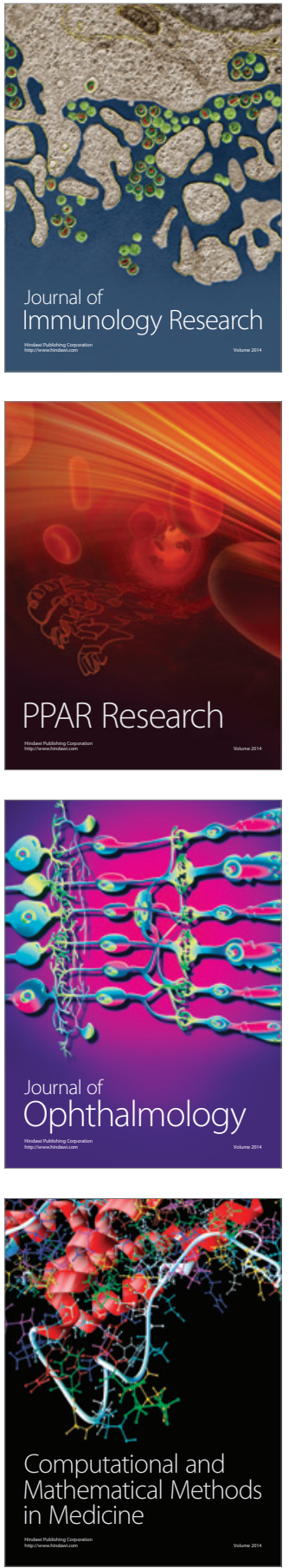

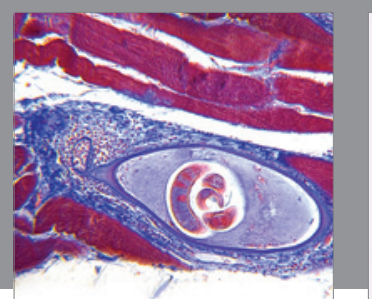

Gastroenterology Research and Practice

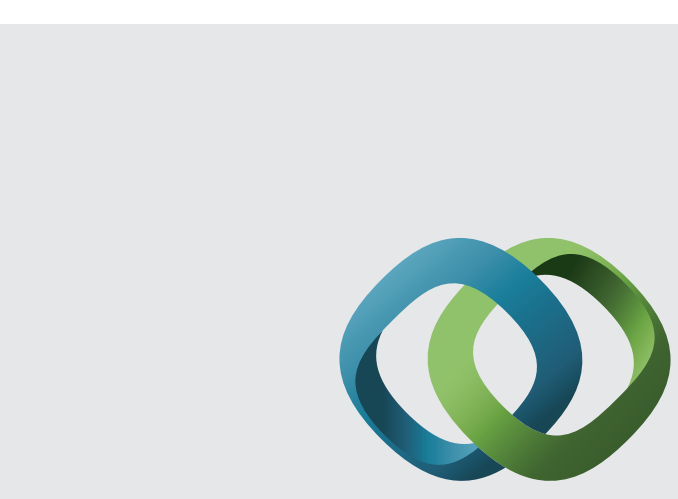

\section{Hindawi}

Submit your manuscripts at

http://www.hindawi.com
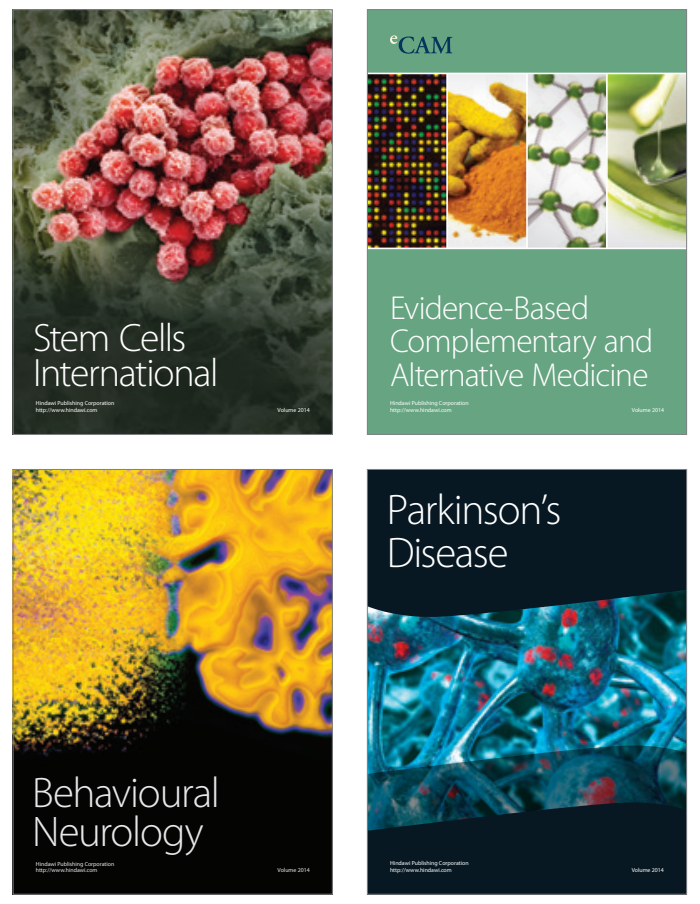
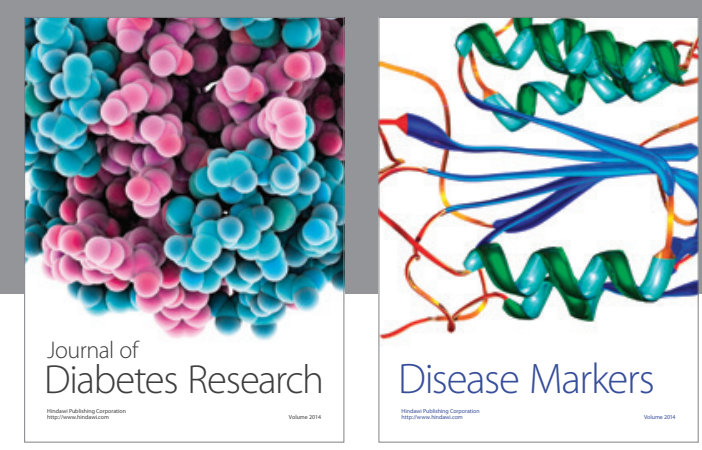

Disease Markers
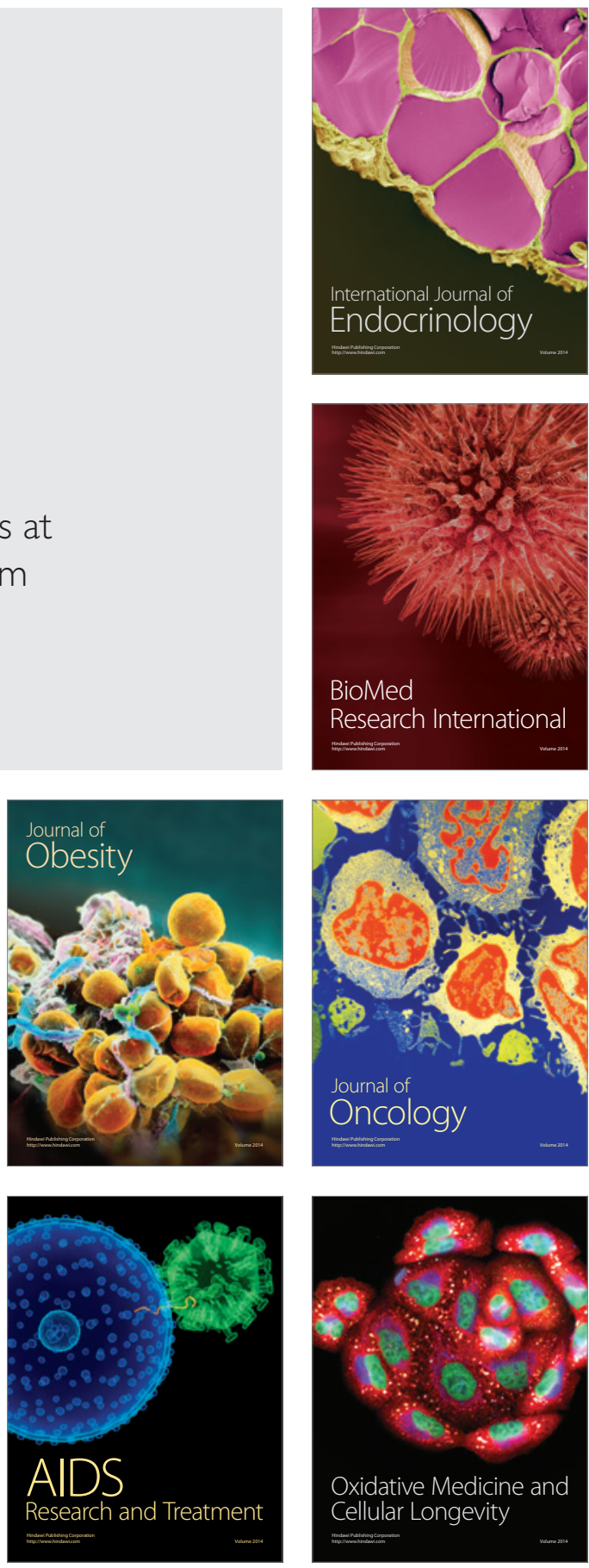